\title{
Syntactic Behavior of Subordinate Clauses of Time and Condition in Zubairi Arabic
}

\author{
Majid Abdulatif Ibrahim \\ Faculty of Arts, Al-Zaytoonah Private University of Jordan, Jordan
}

\begin{abstract}
Of all outstanding areas of syntax, subordinate clauses of time and condition play a great role in arising linguists' interests. These types of clauses are of idiosyncratic nature in general and in Zubairi Arabic in particular, since they tend to be difficult and complex in comparison with other languages and dialects. The present study is an attempt to examine how conditional and time clauses behave syntactically in Zubairi Arabic. It is based mainly on conversation of two Zubairi Speakers from. Looking at this type of conversational speech illustrates a wider range of syntactic structures, and some speakers have more conservative dialect than others, but generally all are Zubairi in character.
\end{abstract}

Index Terms - past punctual, perfective, open punctual, open habitual, open stative and unfulfilled

\section{INTRODUCTION}

A number of recent studies have examined conditional clauses in Classical Arabic. However, a little has been devoted to the study of these structures in its colloquial dialects. In Arabic linguistic studies, interest notably increases in scrutinizing such types of clauses, since they represent an area of syntax, which seems more difficult and complex in comparis on with that of other languages, say English, for example (Palva, 1980; Peled, 1987). A further point of interest that leads to investigate this area, particularly in the domain of Zubairi Arabic, is the multiplicity of conditional and time particles including in, $l \bar{o}$ and $k \bar{a} n$ signifying 'if', la mma and jōm signifying 'when' and ila signifying 'if' or 'when'. It is worth underlying that factors may be found to condition the choice of these particles. However, in this dialect, conditional and time structures sometimes come very close together and are in some cases indistinguishable, or to put it in another way, they may be translated into English with 'if' or 'when'. The two types of these clauses also share various characteristics which will be pointed out in some detail below, but in particular, many of them show a marker on both the main and subordinate clause.

To some extent, Zubairi conditional and time clauses are treated here as being sub-types of one general class of clause, because they are structurally distinguished from the other main type of time clause, the $\hbar \bar{a}$ or 'clause of attendant circumstance', equivalent to a present continuous time clause introduced by 'when' or 'while' in English (Wright, 1975, p. 330). Here, the time clause is introduced by the linking $w$ - 'and', followed by a noun or pronoun and shows a verb in the imperfective, a participle or a non-verbal clause following the main clause.

The present study is an attempt to examine how conditional and time clauses behave syntactically in Zubairi Arabic. It is based mainly on a home conversation between two Zubairi speakers, which was recorded in 2008. The speech is presented in a form of phonemic transcriptions and then translated into English (see Appendix (1)). Looking at this twospeaker conversation illustrates a wider range of syntactic structures, and one of speakers has more conservative dialect than the other, but generally both are Zubairi in character.

\section{CONDIT ION AND TIME CLAUSES: AN OVERVIEW}

Examining these condition and time sentences in general entails that the areas of structure, function and reference must be taken into account. The term 'structure' refers to the actual form of the syntactic unit being considered, expressed in terms of the order of the elements of main and subordinate clauses, in the form of the verbal elements occurring and in the initial marker of the subordinate (Peled, 1985, p. 213). The term 'function' covers the grammatical component of meaning and terms such as 'past punctual' and unfulfilled condition' used below are terms operating on the level of function. Certain distinct structures are regarded as having identical function so that it is not true that each structure may have its own exclusive function. The term 'reference' involves the contextual component of meaning or that area not signaled by the form of the words themselves (Lewin, 1976, p. 148). Some sentence types which are similar in structure and function may have different reference, and consideration of reference is particularly important in dealing with condition and time structures, since in some cases, the time refe rence can be inferred only from the context and above all 'reality' or 'unreality' of a condition may also be inferable from context. Thus, in these cas es, the extralinguistic and linguistic context provides the other component of the meaning of the sentence (Davies, 1987, p. 31).

A time clause can be defined as "one where the occurrence of the action is not in question, but where the time of occurrence is, at least in future events, not known. A conditional clause on the other hand is one where the occurrence of the action is itself in doubt" (Ingham, 1994, p. 132). These types of clauses can be thought of as systems of 
commuting terms and a set of two interrelated systems are recognized in that both take a verb in the perfective and precede the main clause. Adopting the Arabic conception of these types of subordinate clauses discussed by Stwart (1987: 65) gives the following schema:

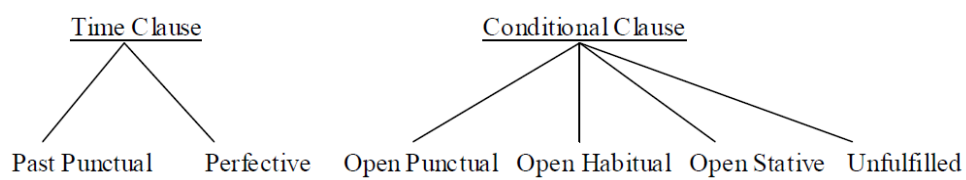

In Zubairi Arabic system, it seems that all future events (being uncertain) are looked upon as conditionals, although in some cases like ila barad alwagt..., "when winter comes..." the arrival of winter is a total certainty. In this type, there is no distinction between 'if' and 'when' clauses in the future when marked by ila. For example, such a sentence as:

ila farēna $\int a j j$ lib isnāh bittanāwab

can be rendered into English as either: "if we buy anything (clothes), we wear it in turns" or "whenever we buy anything, we wear it in turns".

The clause types are dealt with below under their two main headings Conditional and Time Clause. Conditionals are treated first because of their greater complexity, which makes it easier to understand Time clauses within the context of Conditional clauses than vice versa. It is worth noting that certain markers are specialized for time/aspect reference. Thus, in generally refers to the future, $k \bar{a} n$ denotes the present stative, and jōm stands for the past punctual. The particle ila is the most general and can refer to future, present, habitual present or past. In this regard, Sowayan (1990, p. 53) gives a full account of this type of clause, stating that the verb of the subordinate clause introduced by jōm is generally (but not always) in the perfect. If the verb of the following main clause is in the perfect then no particles intervene between the two clauses, but if the verb of the main clause is in the imperfect or if the main clause is non-verbal then it is separated from the subordinate clause by such particles as tāiri and ilja tāari.

\section{CONDIT IONAL CLAUSES}

\section{A. Open Punctual Condition}

These types include clauses which have reference to the future marked by ila, in and $l \bar{o}$ or to the general present marked by ila all being followed by a verb in the perfective. They are termed punctual in order to distinguish them from the stative and habitual types. The inclusion of the particle $l \bar{o}$ in this group may be surprising in view of its usual association in Standard Arabic with unfulfilled or remote condition. However, it is not often possible to differentiate any element of unreality in condition though an element of hesitancy or uncertain ty is there making the use of $l \bar{o}$ rather than in or ila a matter of register signifying politeness or formality. It has been noticed that there is no formal marking of the difference between future conditions and general present conditions marked with ila, and the difference is one of semantic reference rather than grammatical function, which is, in turn, obvious only through a context. In some sentences, no particle occurs at all, but the verb in the main clause is perfective; it resembles a conditional sentence in all except the presence of the particle which can be taken to be there via implication. The following are sentences in which particles in, $k \bar{a} n$ or $l \bar{o}$ are deleted:

(in) ma fih $\int a j j$, , firibt itft $\mathrm{a} j \mathrm{j} w$ tuwakkalt Sala llah

"(If) there is nothing (to do), I will drink so me tea and leave".

(kān/lō) ma tabīnih, radżł̧aৎih irrā؟ijtih w ma sār $\int a j j$

"(If) you (f.) don't want it, you give it back to its owner and it is as if nothing happened".

(a) Sentences marked by ila:

ila barad alwagt infàllah, banēna min jidīd

"When winter comes, God willing, we will build a new".

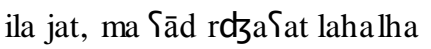

"If she comes (here) he will never again go back to her family".

A number of examples show Open Punctual clauses marked by ila with a non-verbal main clause, and one also with imperfective verb preceded by the presentative particle wila (translated as "behold"):

hatta ila jīt infâllah bāt $\int$ ir ass $\underline{u}$ b $h$, wila-hi dzāh za

"When you come, God willing, to morrow morning (behold) it will be ready"

al-akil ila jīna nākilih, wila-l filfil ak $\theta$ ar min al-timan alli fîha

"When we come to eat the food (behold) the pepper in it is more than the rice".

Sala/àn ila șaffēnāha, wila-hi tins $\underline{a}$ aff

"So that when we stack them (behold) they will be stackable".

ila ja jōm alxamīs al Yasur infallah, wila-k mwallim a yrād ik w intuwakkal Yala llah 
"When Thurs day afternoon arrives, God willing, (behold) you will get your things ready and we will set off".

It is possible that the use of wila in these sentences precludes the conditional interpretation and marks them as time clauses, since the presentatives occur regularly following a Past Punctual Time clause. However, it is difficult to elicit contrastive examples in these cases. The above sentences have future time reference, but the same formal structure may have universal or general time reference as in:

wila Satētih, jiSti jē rik

"And when you give it to him, he passes it on to somebody else".

ila ja dōrik, tāxið

"If your turn comes, you take (one)".

ila sāâr ma Sindih tas rī̄

"If he has no a permission you do not allow him (to do it)".

ja zēn ila sāâr xas mik min ahal dīratk

"How good it is if you adversary is of your own country".

The ele ment $\underline{\underline{a}} \bar{r} r$ "to become" occurs where the following clause is non-verbal or has an imperfective verbal form. In this function, it seems to be parallel to the use of $k \bar{a} n$, which introduces a stative conditional clause. In fact, it is not easy to distinguish a difference of meaning between the two alternatives, but it may be stated that the use of $\underline{s} \bar{a} r$ introduces a further stage of remoteness meaning "if it happens that ..." in comparis on with kān tabi "if you want..." (now), in bayēt "if you want..." (at any time) and la sirt tabi "if it happens that you want..." (in any eventuality). In other areas of the conditional sentences, a number of alternative structures can be used as semantic equivalents. Similarly, some English speakers have three stylistic alternatives for the conditional structures, i.e. "if you want...", "should you want..." and "in the eventuality that you should want..." (Quirk et al, 1985).

(b) Sentences marked by in:

Though less common than ila, the particle in is frequently used to signify 'if' in this dialect. It differs from ila in being definitely conditional and not being susceptible to translation like 'when'. It always has future reference and is followed by a verb in the perfective:

in ligēt kibdah Sala darbik, jīb maßēk

"If you find any liver on your way, bring it (i.e. buy it)".

in allah jābha, zawadznāh.

"If God brings him, we make him get married".

Here, the possibility of the perfective in the main clause indicates future, which does not occur in the structures showing ila. The use of the particle in is the norm with the verb baya "to want" as in in bajêt "if you want".

(c) Sentences marked by $l \bar{o}$ :

As stated above, the particle $l \bar{o}$ in these sentences does not in all cases have the meaning of remote condition associated with it in Standard Arabic. In Zubairi Arabic, it passes into the realm of stylistic difference marking hesitation on the part of the speaker. Sometimes, it has the sense of a hypothetical condition, i.e. one that can be speculated about but which is not necessarily within the domain of likelihood. The verb following $l \bar{o}$ may be in the perfective or imperfective without any discernible difference of meaning. In fact, $l \bar{o}$ can be considered a true exception to the rule that Time and Conditional clauses have a verb in the perfective. It may be followed by inn- "that" with no apparent change of meaning, for example:

(i) With the perfective:

lō inn wā $\hbar$ id ligālih talab Sala darbih, jwass

"If one finds an errand along the way, he completes it".

(ii) With the imperfective:

lō jmu rrūn Sa lēk a $\iint i l l a h, j$ jū lūnlik " $g$ ōh" $g$ ilt “ $\hbar$ ādirir"

"If your friends come by and say 'let's go', you say 'alright".

lō inn abi wā $\hbar$ din jrakkibli azrār, ma ligēt

"If I want someone to sew on a button, I don't find (anyone)".

\section{B. Open Habitual Condition}

Habitual or repetitive actions are represented by ila with a perfective verb in the conditional clause and the main one. It is worth mentioning that this structure is only partially differentiated from structure Open Punctual, which may also have a perfective in the main clause. Here, one clause type stands for sentences that can be translated into English sometimes with "if" and so metimes with "when" or "whenever" signaling a habitual action. It may be past or present in its time reference depending on context, for instance:

iða tla lat farridzat, wiða farridłat lagga $h$ nāh infāllah

"When it (the bud of the palm tree) sprouts it splits, and when it splits, if God wills, we fertilize it". ila hāwa/tih misak iktāb

"Whenever I scolded/scold him he picked/picks up a book". 
Some examples of structure Open Punctual conditions can also be interpreted as having general time reference, so that an overlap may be expected in reference.

\section{Open Stative Condition}

The particle $k \bar{a} n$ occurs preceding a participle, a non-verbal clause, an imperfective verbal form or a perfective verbal one. All of these can be regarded as stative clauses in contract to the action clauses covered before. At first sight, another exception may be looked upon to the rule of Conditional and Time clauses having a verb in the perfective. However, If $k \bar{a} n$ is considered as being derived from in $k \bar{a} n$ "if it is" in which $k \bar{a} n$ is a perfective verbal form, then these structures follow a general rule. This particle can also be followed by personal pronoun suffixes giving forms such as $k \bar{a} n$-ih "if he", $k \bar{a} n$-ik "if you" etc. In this dialect and in contrast to some Arabic varieties, the particle $k \bar{a} n$ does not inflect for person as seen in the following examples:

\section{(i) With a participle:}

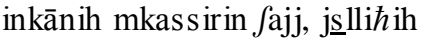

"If he has broken something, he will mend it".

jatk, in kānha mwā figah

"She will come to you, if she is in agreement".

(ii) With a non-verbal clause:

inkān innifarīkat $\hbar$ ajātik $\underline{s} a \hbar \bar{i} h$...

"If I a really the partner of your life ..."

(iii) With an imperfective verbal form:

inkān innik tabi bint xālik, kallamnāha

"If you want (to marry) your cousin, we will speak to her"

(iv) With a perfective verbal form:

inkān inni hawwant halmarrah, fant dzid hawwant alf marrah

"If I have refused this time, you have refused (in the past) a thousand times".

\section{Unfulfilled Condition}

When $l \bar{o}$ marks an unreal or unfulfilled condition it will have $k \bar{a} n$ as a marker on the main clause, which may be followed by a verb in the perfective, an active participle, a non-verbal clause or more rarely an imperfective verb as in:

lō inni ma biStih, kān raddētih Salēk

"If I had not sold it, I would have given it back to you".

lō almiddah tuwīilah, kān a $g \bar{u} l$ ma jxālif

"If the period was long, I would say "It does not matter".

However, some sentences are without $k \bar{a} n$, for example:

lō $g$ iltlik, minti msaddigni

"If I told you, you wouldn't believe me".

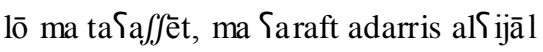

"If I did not have dinner, I would not be able to teach child ren".

\section{TIME CLAUSES}

\section{A. Past Punctual}

These types of sentences are commonly marked by the particle jōm "day" which has punctual significance. If the main clause following the time clause is non-verbal, it must be preceded by one of the 'presentative' particles (i.e. ila, wila mêr, winn). These particles are equivalent to the Standard iðā bi, a deictic particle usually translated 'behold' or 'lo'. In fact, their occurrence is syntactically limited to give them some sort of heavy semantic load when translated as 'behold'. The main purpose they serve is to mark the second clause in a complex structure. In the following examples, the most common presentative occurring here is wila, which is again translated as 'behold so as to ease recognition of its place in the sentence:

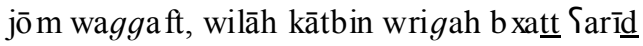

"When I stopped, (behold) he had written a note in large handwriting".

u jōm jōh, wila nasah tigil u tigfi

"And when they came to him, (behold) his relatives were charging back and forth".

In certain contexts, jōm may be followed by an imperfective verb form with past time reference in sentence initial position. This use can be interpreted either as a distinct function or a purely variant of the Past Punctual. Nevertheless, Sentences of this structure tend not to be Time clauses in the same sense as the others, since the clause with jōm does not actually set the time frame of what followed. It is a merely general subordinator giving the meaning of "the fact that...", for instance:

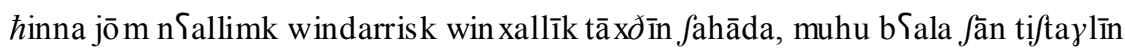


"When we taught you, gave you lessons and let you take certificates, it was not that you would work".

jō $\mathrm{m}$ ink tadrisīn, agul ma Salēh

"When you studied, I (used to) say: 'It doesn't matter"'.

However, these sentences may constitute a different sub-type conveying Past Continuous meaning, for example:

(i) With the perfective in the main clause:

jōm kifaf \{alēh, gāl...

"When he examined him medically, he said...".

jōm $g$ arrubat alimt iћānāt, bidaw jdrūsūn

"When the time of exams approached, they began to study".

jōm daxalt, yajjar abūj madz̧a $1 \hbar \operatorname{ad} \bar{i} \theta$

"When I entered, my father changed the direction of the conversation".

(ii) With the imperfective and non-initial as a sentence component:

xubri min /harēn, jō madzaddid dzawāzi

"My knowledge of this was two months ago, when I renewed my passport".

ana 1 àm jōm arū $\hbar$ lilhind, ligèthum...

"Last year when I went to India, I found that they...".

giltlik jōm tanzil,...

"I told you when you were going downstairs,...".

(iii) With the perfective and following the main clause:

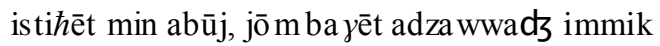

"I was ashamed in front of my father, when I wished to get married your mother".

\section{B. Perfective}

The particle ila can also be followed by min"from" plus a personal pronoun suffix. This indicates that the action of the time clause precedes that of the main clause, which can be in the future or the past. If past, the verb of the main clause will be in the perfective and if future (or general present), it will be in the imperfective as in:

(ii) With future reference:

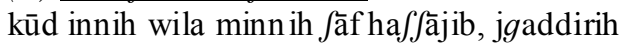

"Perhaps when he sees this old man, he will respect him".

wila minnih alla a ynāk, traddihin

"When God has enriched you, you may give them back".

wila minnik banēt, hāk hassa fih alf hall

"When you built it, then there will be a thousand solutions".

(ii) With past reference:

ilja minni fikēt al $\hbar$ imil, fàlih

"When I complained of the burden, he took it up".

ilja minnik as arrāti Yalēh, wiftabīn ih jsawwi

"When you pressed him, what did you expect him to do?"

\section{CONCLUSIONS}

In general, the subordinate system gives choices in the dimension of probability and reality, i.e. open condition versus unfulfilled and of aspect, i.e. punctual versus habitual, stative or perfective. In the subordinate clause, a perfective verb form is preferred and indicates a punctual action following the time/condition particle. In some cases, the perfective can be replaced by an imperfective when this follows the main clause without any change in time reference. In the main clause, the perfective and imperfective have more reference to time in that the former usually refers to the past while the latter to the future or general present. The significance of the choice of perfective versus imperfective in the main clause plays a vital role in Open Punctual and Open Habitual because it is the major marker of the distinction between the two.

\section{The Vowels}

$\mathrm{i}$ as in mifa "he went"
$\overline{1}$ as in tabīn "you want?"
$\overline{\mathrm{e}}$ as in lēt "I wish"
$\mathrm{a}$ as in aśalli "I prayer"
$\bar{a}$ as in nām "he slept"




\begin{tabular}{|c|c|c|c|c|c|}
\hline as il & d "extra" & & & & \\
\hline as in & mutar "rain" & & & & \\
\hline as in & agūl "I say" & & & & \\
\hline 2. The C & usonants & & & & \\
\hline $\mathrm{b}$ as in & bard "cold" & $\partial$ as in & ðāk "that" & $\mathrm{h}$ as in & hnāk "there" \\
\hline $\mathrm{t}$ as in & tumir "you pass" & $\underline{\partial}$ as in & $\underline{\partial a r f}$ "envelop" & $\mathrm{d} 3$ as in & dzah "he came" \\
\hline$\underline{\mathrm{t}}$ as in & tabx"cooking" & $\overline{\mathrm{s}}$ as in & sūr "fence" & $\mathrm{m}$ as in & mafi "nothing" \\
\hline $\mathrm{d}$ as in & darēt "I hnew" & $\underline{\mathrm{s}}$ as in & salih "good" & $\mathrm{n}$ as in & nūr "light" \\
\hline$\underline{\mathrm{d}}$ as in & dahir "noon" & $\mathrm{z}$ as in & zēn "well" & 1 as in & lēl "night" \\
\hline $\mathrm{k}$ as in & kallam "He talked" & $\int$ as in & fūf "see" & $\mathrm{W}$ as in & wad "send" \\
\hline$g$ as in & agbil "He comes" & $\mathrm{x}$ as in & xōf "fear" & $\mathrm{j}$ as in & jōm "day" \\
\hline$?$ as in & ?amal "hope" & $\gamma$ as in & yani"rich" & $\mathrm{t} \int$ as in & tfāj “tea" \\
\hline$f$ as in & faham "He understood" & $\hbar$ as in & har "hot" & & \\
\hline as in & $\theta$ aruwa "worth" & $S$ as in & Sām "general" & & \\
\hline
\end{tabular}

\section{APPENDIX (1)}

The text is a home conversation of two Zubairi speakers: the first was the husband addressed as Abu Mahmud (symbolized as A) and the second was the wife addressed as Umm Mahmud (symbolized as U).

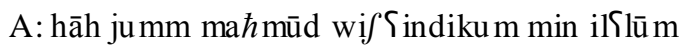

$\mathrm{U}:$ ma Sindina wallahi illa lbiga

A: xēr warā kum jumm ma $h$ mūd Sasa ma farr

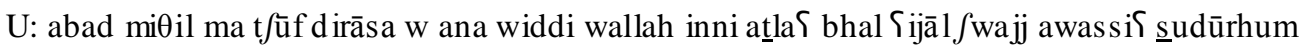

A: ma Sindi māniS bass wēn tabūn trū $\hbar \bar{n}$ lih Sallmūni

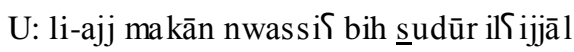

A: ana Sindi fikrah jumm ma $\hbar$ mūd

U: xēr wifhi jabu ma $h$ mūd

A: wara ma nimurr bēt ixti huș sah u nāxiðha hi w iS jālha w inwaddīkum lil malāhi u xallu 1Sijāl jilYabūn u jistānsūn ilēn tigūlūn bas s

U: wallāhi innaha fikrah mimtāzah u Sasallah jxallīk lina jabu ma $\hbar \overline{m u ̄ d}$

A: Sjal inti nādi 1 ijāl u xallīhum jistiSiddūn w ana baka lim uxti axallīha tistaSidd hi wa Sjālaha fima nimu rrhum U: zēn ma jxālif rabbi jxallik lina jabu ma $h$ mūd

A: bsur\{a ju mm ma $\hbar$ mūd tara ma Sindina wagt

U: wala jhimmik $\left\{a \int a r\right.$ da $g$ ājig u tilgāna rākbīn issajjārah

A: jallah tuwakkili Sala llah

U: hāh jabu ma $h$ mūd kallamt $\hbar$ uss ah

A: aj naSam u giltilha ttwallam hi w iS jālha

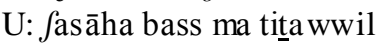

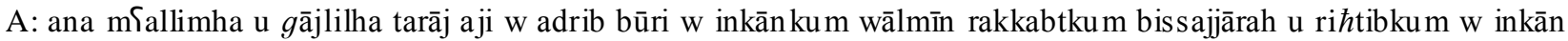
ma wallamtumriht u xallettkum

U: walaw giltalha halkalām ma fîh fājdah

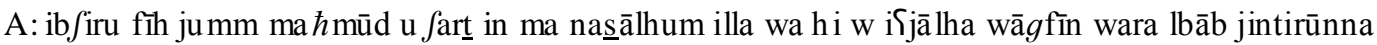

\section{$\underline{\text { Translation }}$}

A: What news do you have, Umm Mahmud?

$\mathrm{U}$ : By God, we have no news except that we remain alive.

A: I hope there is nothing wrong, Umm Mahmud.

U: Nothing, it is as you see all studying and revision and I would really like to take the children out for a while and give them some amusement.

A: I have no objection, but where do you want to go. Tell me.

$\mathrm{U}$ : Anywhere we can give the children some amusement.

A: I have an idea, Umm Mahmud.

$\mathrm{U}$ : Well, what is it, Abu Mahmud? 
A: Why don't we call on my sister Hussah and take her and her children and I take you all to the Fun Fair and let the children play and enjoy themselves as much as you want.

U: Well, it seems like a marvelous idea. God preserve you for us Abu Mahmud.

A: So, you can call the children and let them get ready and I will call my sister and let them get ready and in the meantime we will drive over there.

$\mathrm{U}$ : Good that is alright. God preserve you for us Abu Mahmud.

A: Hurry Umm Mahmud, because there is no much time.

U: Do not worry within ten minutes we will be ready in the car.

A: Come on then let's go.

U: Abu Mahmud, did you speak to Hussah?

A: Yes, and I to ld her to get ready with her children.

$\mathrm{U}$ : I hope she will not be late.

A: I have told her and said to her that I will be coming by and will sound the horn and if you are ready I will put you in the car and take you with me, but if you are not ready I will go and leave you.

$\mathrm{U}$ : If you tell her this, it will be of no use.

A: I hope that it will not happen Umm Mahmud and I warrant that as soon as we reach their house, they will be down by the door waiting us.

\section{REFERENCES}

[1] Davies, E. (1987) “Some Restrictions on Conditional Imperatives”, Linguistics, 27, 31-54.

[2] Ibrahim, Majid Abdulatif. (2006). Syllable Structure and Syllabification in Zubairi Arabic: A Phonological Study from a CV Perspective. Unpublished Ph.D. Dissertation. Basrah: University of Basrah.

[3] Ingham, B. (1997). Arabian Diversions: Studies on the Dialects of Arabia. Reading: Ithaca Press.

[4] Lewin, B. (1983). "Non-conditional Clauses in Arabic", ZDMG, 25, 264-70.

[5] Palva, H. (1980). "The descriptive Imperative of Narrative Sty le in Spoken Arabic", Folia Orien talia, 29, 5-26.

[6] Peled, Y. (1985). "On the Obligatatoriness of $f a$ in Classical Arabic Conditional Setences", JSS, 30, Vol. 2, 213-26.

[7] Peled, Y. (1987). "Conditional Sentences without a Conditional Particle in Classical Arabic Prose”, ZAL, 26, 31-43.

[8] Quirk, R., Greenbaum, S., Leech, G., and Svartvick, J. (1985). A Comprehensive Grammar of the English Lan guage. London: Longman.

[9] Sowayan, S. (1990). The Arabian Oral Historical Narrative: An Ethnographic and Linguistic Analysis. Wiesbaden: Otto Harrassowitz.

[10] Stewart, F. (1987). “A Bedouin Narrative from Central Sinai”, ZAL, 16, 44-92.

[11] Wright, W. (1975). A Grammar of the Arabic Lan guage. Cambridge: CUP.

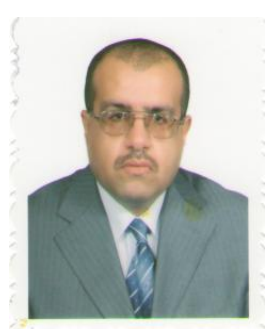

Majid Abdulatif Ibrahim was born in Zubair, Basrah, Iraq in 1970. He received his Bachelor's degree in English and English Literature from University of Basrah, Iraq in 1992, a master's degree in Applied linguistics/Phonetics and Phonology in 1994, and his Ph. D. in General Linguistics/Phonetics and Phonology program in 2006.

He was a member of the Department of English, University of Shatt-el-Arab from 1997 until 1999. From 1999 to 2009 he served as a teaching staff member of the Faculty of Arts, University of Basrah, where he became an Assistant Professor of Phonetics and Phonology. When leaving Iraq, he served as an Assistant Professor of Lin guistics and Phonetics at the Faculty of Arts, Al-Isra Private University of Jordan from 2009 until 2011. Then, he has been working as Assistant Professor of Linguistics and Phonetics at the Faculty of Arts, Al-Zaytoonah Private University of Jordan since 2011. His current areas of interest are Phonetics, Phonology, Syntax, Phonology of Iraqi and Gulf dialects. Dr. Ibrahim resides in Amman, Jordan, with his wife and their two children. 